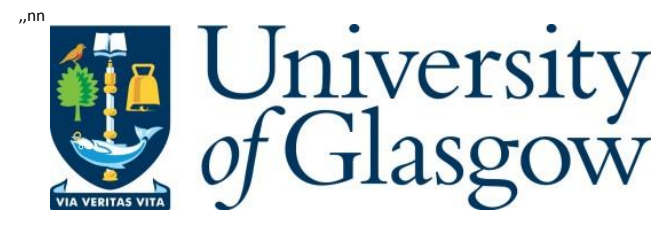

Slade, G. (2017) Remembering and forgetting the Gulag: prison toursim across the post-Soviet region. In: Wilson, J. Z., Hodgkinson, S., Piché, J. and Walby, K. (eds.) The Palgrave Handbook of Prison Tourism. Series: Palgrave studies in prisons and penology. Palgrave Macmillan. ISBN 9781137561343Copyright

(C) 2017 Palgrave MacMillan

This extract is taken from the author's original manuscript and has not been edited. The definitive, published, version of record is available here:

http://www.palgrave.com/gb/book/9781137561343

http://eprints.gla.ac.uk/138346/

Deposited on: 15 March 2017

Enlighten - Research publications by members of the University of Glasgow http://eprints.gla.ac.uk 
Published in: Wilson J.Z, Hodgkinson S., Piche J. \& Walby K (2017)The Palgrave Handbook of Prison Tourism. Palgrave MacMillan UK

\section{Remembering and Forgetting the Gulag: Prison TOURism aCross the POST-SOVIET REGION}

Gavin Slade

University of Glasgow

\section{Abstract}

This chapter provides a comparative account of prison tourism in the post-Soviet region. It juxtaposes prison tourism in the Gulag center of Russia and Kazakhstan countries where the Soviet system of labour camps was most prevalent - with the Gulag periphery of the Baltic States - countries where less remains of Soviet penal structures, but a sense of national victimhood is higher. The chapter is broadly organized around four key variables for comparison: the physical location of the sites; the representations of victims and perpetrators in museum objects; the degree of commercialization; and the narrative of making a break with the past and concealing continuities with the Soviet system. The chapter finds big differences across the cases in terms of these variables. However, it argues that one thing prison museums throughout the region share is a lack of engagement with the issue of penal reform and the degree to which elements of the Soviet system of punishment still endure.

\section{Introduction}

In the middle of the Kazakh steppe gleaming skyscrapers punctuate the horizon. Entirely new buildings combine to produce a bizarre cityscape that seems to borrow from New York, Dubai and Tsarist, as well as Stalinist, Moscow. This is Astana, the new capital city of Kazakhstan, built in less than 20 years, in a blistering spurt of construction. Forty minutes drive out into the steppe away from the new city centre brings you to a small town called Malinovka. It seems a typical Soviet settlement. Six-storey blocks of flats from the 1960s and 1970s line the roads replete with Soviet murals celebrating space travel. At odds with its environment, a bizarre cone-shaped tower emerges from behind some bushes 
next to the highway. It is distinctly un-Soviet. Getting closer, a small marble bunker emerges into view, then an empty car park and a mocked up watchtower, a uniformed mannequin atop it, barbed wire around it. This is the Alzhir Museum for the Victims of Political Repression. It is situated on the old site of a special camp in the system of Soviet penal institutions known as the Gulag. The camp had once exclusively held the wives of so-called traitors' to the motherland.

Along with Siberia and the Urals in Russia, Kazakhstan was at the centre of the Gulag system. It makes sense to find some prison museums there. Yet, memorializing the Gulag in Kazakhstan is a highly contentious issue, as it is throughout the post-Soviet region. The purpose of this chapter is to discuss this contentiousness and introduce the region as a fascinating, evolving site for investigating dark tourism. What makes the region interesting to scholars of prison tourism is the way in which sites of Gulag memorialization have come to vary across the region, despite the Gulag being a common source of suffering across the nationalities that made up the Soviet Union. This chapter aims to provide an original analysis of this variation building on the prison tourism literature. The chapter is a unique comparative account of an understudied area of prison tourism (Ross 2012) and is based on empirical observations from Lithuania, Latvia, Russia, and Kazakhstan.

The chapter will show that comparing post-Soviet states reveals political and 'cultural projects' (Welch \& Macuare 2011) in framing the experience of Sovietization in the present day. These projects are revealed in how particular types of Gulag sites are memorialized in these countries. Specifically, four key variables underlie the discussion below of the region's prison tourism. These variables are:

- The physical location of the sites and the locations' relationship to the Gulag system;

- Representations of victims and perpetrators of the Gulag in museum objects;

- The tensions between education and entertainment in these sites;

- The extent that museums draw a line under a now distant past and thus conceal continuity in practices of punishment today. 
On this final point, the chapter shows that, as has been observed elsewhere (Walby \& Piche 2011), 'dead prisons' and prison museum sites 'reconfigure living prisons' (Brown 2009: 120) and hide uncomfortable links with current punishment practices. This is not something new in the region. Hardy (2012: 76), in an excellent analysis of Gulag tourism in the 1950s, stresses that while foreigners were invited to visit working Soviet penal sites to show off the superiority of the Soviet form of modernity, the management of these visits suppressed 'the challenges of reform and the persistence of violence and other problems.'

Finally, the chapter, where possible, analyses possible explanatory factors for variance. In doing so, it makes mention of the way Gulag museum sites link to national narratives, political expediency, and orientations towards remembering and forgetting the Soviet past. To do this, the chapter compares and contrasts cases from the center of the Gulag system - Russia and Kazakhstan - with its periphery, focusing on the Baltic States of Lithuania, Latvia and Estonia. Before turning to this comparison, I briefly provide an overview of the Gulag as a historical phenomenon.

\section{The Gulag in History}

Beginning at the end of the 1920s, the Gulag was a system of penal institutions, and in particular camps, that stretched across the Soviet Union. It was a vast system that at its height held almost three million prisoners, with many more monitored in so-called special settlements (Getty et al. 1993; Bacon 1994). There has been much debate over the purpose of the Gulag. From one perspective, it appears as a purely economic system, a way of putting to work undesirable elements of society in geographic places where nobody would otherwise choose to work (Gregory \& Lazarev 2003; Borodkin et al 2005). From this point of view, the Gulag was also a form of internal colonization (Viola 2007; Etkind 2013). Convicts settled and developed entirely new areas of the Soviet 
Union. The Gulag was not a pure extermination system and does not stand comparison with the concentration camps of the Nazis. For one thing, the Gulag kept up the pretense of being part of a criminal justice system. Convicts passed through arrest, investigation and trial however farcical and quick these procedures were. If not sentenced to execution, convicts entered a system that intended to squeeze productive labour out of them, but also, on the face of it at least, aimed at keeping them just about alive, to redeem them and reform them into good Soviet citizens (Barnes 2011).

One of the curious aspects of the Gulag was the array of institutions that it encompassed. Only one percent of the total convicted prison population was actually held in cellular confinement known as prisons [tyurmy] (King 1994). The vast majority of prisoners were kept in collectivist camps and so-called colonies. These were built with socialist ideology in mind - the goal of these institutions was to reform deviant individuals into the Soviet mold. This was achieved by collective living with prisoners inhabiting dormitories en masse, forming collectives, working in teams and learning Soviet propaganda. Prisoners submitted to a double surveillance from both the camp administration as well as the self-governance forms that emerged among the inmates themselves (Kharkhordin 1999; Piancentini \& Slade 2015). Camps were maintained in sectors that stretched over hundreds of acres. Thus, for example KarLag refers to the administration of the Karaganda Gulag camps in today's Kazakhstan. Karlag governed a huge territory - 300 kilometres north to south and 200 east to west divided into sectors with dozens of camps on the space of each one (Barnes 2011). Living an exceptionally harsh, communal and open life, prisoners were relatively mobile in the Gulag. In some camps they left the living quarters during the day to work cutting wood, building roads, or mining (Applebaum 2003). Those exiled in special settlements worked on state projects and mingled with the local population. However, they were still technically prisoners, exiled from their homelands, restricted in their movement and engagement with society (Viola 2007).

Yet, the camps and colonies invoked by the word 'Gulag' hide the fact that a multitude of other carceral institutions made up this penal system. Entrance into the Gulag started with the investigative cells of police stations, pre-trial 
detention in the jails, and the prisoner train wagons that trundled through endless steppe and taiga for weeks to bring convicts to the camps (Pallot \& Piacentini 2012). Some non-political crimes and first time offences were punished in small-scale colonies close to home.

After the death of Stalin in 1953, the size and extent of the Gulag was significantly decreased. The biggest, harshest camps were closed down or converted into clusters of smaller colonies. In the late 1950s, as the Cold War reached its height, the Soviet Union presented its penal system as a superior more humane vision of punishment and corrections. At this time, a form of 'Gulag tourism' was developed. Foreigner delegations were invited to tour functioning penal facilities, meet prisoners and stay for vodka and cake with the governor (Hardy 2012). Only four facilities were opened up like this and were most likely prepared for this purpose as show prisons (Ibid.). In any case, this form of Gulag tourism was short-lived as the system became more punitive again in the 1960s.

The institutions of the Gulag in some form or other existed on the territory of all Soviet Socialist republics. The large administrative 'zones' that held the most notorious camps were in eastern Russia, the Ural mountains and Kazakhstan. Nevertheless, it is true to say that each successor state of the Soviet Union has its own history and relationship with the Gulag. This is framed both in terms of the sites that still remain in each country and the relative suffering of the population. Thus, while Russians were the most populous ethnic group in the Gulag, as a proportion of the population Latvians and Lithuanians in particular suffered disproportionately, and pre-1934 Ukrainians were excessively repressed relative to the population (Getty et al 1993).

A sense of victimhood and the presence of sites of suffering strongly affect how the Gulag is represented and remembered in each successor state, the form and content of museums, and what is done with the old places that were once part of this continent-sized penal system. Moreover, this relationship with the past is mediated by how the successor states of the Soviet Union have, 24 years after the collapse, all diverged in their political and economic profile, geopolitical alliances, and attitude to the Soviet experience.

In what follows, I will discuss how the relative weight of Gulag history bears today on how that history is memorialized in prison museums in different 
countries in the region. To do this, I divide the region up into a Gulag center and a Gulag periphery. The center includes the two biggest republics where most of the sprawling camp 'zones' were situated: Russia and Kazakhstan. A semiperiphery can be drawn around Ukraine and Belarus, large Slavic republics adjoining Russia but still relatively far from the Gulag centre. Lastly, the periphery consists of the countries of the Baltic States, the Caucasus and Central Asia excluding Kazakhstan. Periphery countries are generally small both territorially and demographically. They exist far from the camp zones of Siberia or the Urals but their peoples were often disproportionately represented in the Gulag. These geographic distinctions I intend only as a heuristic device in thinking through variation in memorialization of the Gulag, though there is much variation within these geographic blocs as well as I will discuss. The rest of the chapter now looks at examples of the center and periphery drawing out variations and differences in the prison tourism that occur in these countries according to the four variables laid out in the introduction: physical location; representations of victims and perpetrators; education versus entertainment; and the concealment of continuity with the present day.

\section{The Center: Gulag Museums in Russia and Kazakhstan}

The Soviet past in present day Russian politics has become an important issue of contention. There has been a tendency to view the revanchist regime of Vladimir Putin as an attempt to resurrect aspects of the old Soviet empire. As such, the past crimes of that empire are not ones to be remembered or memorialized. Of these crimes, the Gulag penal system is one of the biggest. Putin's neo-Sovietism, it is claimed, is revealed by his often-quoted suggestion that the collapse of the Soviet Union was the 'greatest geopolitical disaster of the $20^{\text {th }}$ century,' his immediate resurrection of the old Soviet anthem's music, albeit with different words, upon becoming president in 2000, his glorification of the Great Patriotic War (WWII), positive portrayal of the Bolsheviks in new official school textbooks, and at best neutral positions about Stalin and at worst a lowkey rehabilitation of him (see Shevstova 2010; 2012). 
This view of the Putin regime requires important qualifications though. Putin is certainly a former KGB man, but he has little allegiance to many aspects of communist doctrines, concerning the command economy for example, restrictions on religion, class struggle, or the notion of revolution. Moreover, Putin is not uncritical of the Soviet past. In terms of the Gulag, he has described Alexander Solzhenitsyn's Gulag Archipelago as 'essential reading' for all Russians (Isachenkov 2010). While Russia since 1991 has been slow to reform its prison system, it has signed up to international treaties and protocols against torture and for human rights and current, though overly ambitious, policy aims to end the camp system of punishment in favor of cells by 2020 (Piacentini \& Slade 2015).

In terms of prison tourism, Russia maintains a number of museums and tourist sites connected to the Gulag. Controversy has swirled around these in the time that Putin has been in power. In the autumn of 2015, a new Gulag museum opened in central Moscow, replacing an older one. Neither the new or old museums are on old prison sites. The old museum displayed a number of exhibits maintained on two floors in a classical central Moscow house. When the author visited in 2011, it contained re-makes of cells and dormitories of the camps, a mock up watchtower outside, pictures and stories of survivors, photo exhibits of the camp locations, and rooms that gave sweeping overviews of Gulag history. This museum opened in the early 2000s. It has been supplanted by a much bigger, new museum, costing \$4.7 million (Amos 2015). This new Gulag museum uses artifacts, testimonies and archives, including personalized accounts of victims and families called 'My Gulag.' It will include a memorial close by, placed on a street named after political dissident Andrei Sakharov, to the Victims of Political Repressions. This memorial will be of a much larger scale than the current one, a large, simple rock from the Solovetsky Islands - one of the first places of the Gulag archipelago - positioned quietly and unassumingly near the KGB building on the Lubyanka Square.

The existence of this new museum appears to suggest an openness to the past and a willingness to develop prison tourism. However, while Sakharov Street is to get its new memorial, the Andrei Sakharov Centre, a human rights foundation and museum that, among other things, provides exhibits on Soviet 
totalitarianism and the Gulag, was investigated in 2014 by the Justice Ministry. Similarly, the human rights group Memorial, which also maintains exhibits, information and documentation about the Gulag in its Moscow offices, was ordered shut down. This was thankfully overturned by a court decision in 2015 . Both institutions were accused of being undeclared 'foreign agents' and thus falling foul of a new law introduced in 2013 that requires all organizations that receive foreign support to register as such (Radio Free Europe 2014). Sites commemorating the victims of the labor camps around the monasteries of the Solovetsky Islands have also come under pressure. Exhibits about the Gulag within the monastery complex, a prison during the early Soviet period, have been pushed out to a nearby museum which, according to one journalistic report, de-emphasizes prisoner hardships (MacFarquhar 2015).

The foreign agent law was also invoked to pressure the one museum that is actually situated on a former Gulag camp. The site, Perm-36, near the city of Perm in the Ural mountains had been run by a local NGO from 1996 onwards. In 2013, the Culture Ministry announced it would take over the site, removing mention of Stalin and turning it into a museum to the Soviet penal system as opposed to a memorial to political repression, despite the fact that the camp itself had held political dissidents into the 1980s (Oliphant 2015). Thus, visitors to Perm-36 are now told about its achievements in timber production as opposed to the repression of political prisoners.

A host of reasons, other than foreign financial support, were cited as behind the decision to take over the site. The local governor of the Perm region changed in 2012 and the new appointee has been keen to please the federal government. The museum was financially unviable in the form it was in and needed greater state backing, which would not be forthcoming while it was run independently. The museum held open days and events to openly discuss the Soviet past; this had led to some complaining that it was 'anti-Russian'. Whatever the full reason, the last museum on an actual Gulag site in Russia became a centre of struggle for control over memory. Sadly, in March 2015, and as of the time of writing, the museum is slowly closing down to visitors.

A central factor in explaining the diametrically opposed fortunes of the Moscow Gulag museum and the Perm-36 camp lies not in the denial of the Gulag 
or its reality per se but the role the state, and in particular the country's leaders, played in its creation and actualization. This is all the more so given Russia's incarceration rate - one of the highest in the world - lack of penal reform and accusations of political persecution of certain individuals. The Russian government clearly favours a form of prison tourism where interested parties are distanced from authentic experiences of the Gulag by displays of relics and mock up watchtowers in a custom-built museum in Moscow as opposed to an actual Gulag site.

Interestingly, museums in pre-Soviet jails, as opposed to the camps of the Soviet era, are far from threatened. Such jails are still in use, often as remand centres or as lock ups for the worst offenders. One of the most popular destinations for prison tourists is the Vladimirskii Tsentral jail in Vladimir, a town a couple of hours east of Moscow. An infamous prison, built in 1793 and immortalized in criminal songs known as shanson, the prison museum is small with a couple of rooms displaying prisoner artifacts and art, and historical information about the prison (Moscow Times 2003). This particular prison museum, with its shocking prisoner weapon displays and flamboyant mannequins of tattooed prisoners convicted of common crimes, can again be juxtaposed with that of the more sober and doomed Perm-36 Gulag camp museum, a place that had been populated mainly by starving political prisoners. It is perhaps not so surprising that the prison museum in Vladimir appears safe from central government interference.

Outside Russia, Kazakhstan has the most Gulag sites of any former Soviet republic. And, like Russia, it also has an uncertain relationship to these sites and the development of prison tourism - an uncertainty that reflects a more general tension in the national narrative concerning the Soviet past. This tension emerges out of Kazakhstan's recasting of itself as a fundamentally futureoriented country. Kazakhstan-2050, a project to lift the country into the top tier of developed countries by the year 2050, is proclaimed from hilltops, on billboards and in dedicated rooms in the smallest of regional museums to the largest national museums.

The autocratic president, Nursultan Nazarbayev, has been at the country's head since the 1980s. As in Russia, there is no incentive among the country's 
elite to develop a tourism sector that highlights the repressive historical role of the country's leaders. Moreover, drawing constant attention to the suffering of Kazakhs under the Soviets may lead to fissures with the significant ethnic Russian minority, comprising some $25 \%$ of the country. Indeed, the victims who toiled in Kazakhstan's steppe were largely not Kazakhs, but of many nationalities, including large numbers of Russians. Thus, Gulag memorialization is a highly sensitive cultural and political project and prison tourism sites are carefully managed and left largely unvisited in far-flung places.

The Alzhir museum to the victims of political repression on the site of the former camp that interned the wives of the traitors of the motherland, discussed at the beginning of the chapter, portrays this. The museum was opened in 2007 on the orders of the president, whose words on learning from history adorn the museum entrance. On the one hand, it is a clear government investment in acknowledging the repressions visited upon people during the Soviet past. On the other hand, it is a political project, carefully managed, just like democracy, to gain recognition for the acknowledgment of past horrors at the same time as emphasizing present stability and future glories.

Thus, the words of Nazarbayev, a man who has repressed all forms of political opposition himself in the present day, are quoted in various places in the museum. As all museums in Kazakhstan, Alzhir also hosts a light blue room the colour of the Kazakh flag - celebrating the constitution, Nazarbayev, and Kazakhstan-2050. This is positioned just before the visitor passes up some stairs to find the wretched personal objects of camp internees requisitioned by the Soviet state. Alzhir is also hard to get to. There is no special bus service from Astana. When the author visited on a warm, sunny weekday in the middle of June there were no other visitors. Later, a schoolbus turned up and a group of children hopped out to run through the cone-shaped tower - an oddly incongruent 'arch of grief' which appears to be motivated by the current political penchant for modern architecture, rather than enabling an authentic experience of Gulag life.

Yet the Alzhir site does not aim for authenticity, it is a spectacle which pays tribute to the progress of the new Kazakhstan as it leaves its Soviet past behind. Standing in the grounds of the museum it is virtually impossible to get 
any sense of what once was here. There are no physical traces of the old infrastructure, nor is there any longer a sense of the extreme isolation of the place as it was in the 1930s. The town of Malinovka grew up after the camp was closed. When pushed, a museum guide explained that the women incarcerated at Alzhir had planted the trees around the site, now blocking the view towards some apartment blocks and a petrol station. Otherwise, a mass grave left forgotten out past the military base on the edge of town is all that physically remains of any part of the camp.

It is also hard to imagine that the Alzhir camp was just one among hundreds that were grouped into sectors, sprawling over hundreds of square miles, and governed by one administrative body out of one office, now another museum, a couple of hundred kilometres to the south. This huge system, KarLag, held dozens of camps and was populated by thousands of prisoners. The centre of KarLag was Karaganda, a once desolate mining town in the middle of the steppe, founded in the $19^{\text {th }}$ Century. There are a couple of sites for prison tourism there too. To the south of the town, near a small military settlement called Spassk, there is a memorial to foreign victims of the Gulag positioned on the site of the KarLag sector for prisoners of war. Here commemorative plaques from around Europe stand silently next to a mass grave. The site appeared to be rather unknown to locals and there are no signs of the Kazakh government at the site, or of any promotion of the site as a place for visitors.

Around 30 miles to the west of Karaganda, in a small village called Dolinka, the Soviets built an administrative building to operate as the nerve centre of this country-sized network of camps, including the POW camps at Spassk and the wives of traitors camp at Alzhir. The building at Dolinka has recently been repaired and houses a new museum. The building sits strangely in the village of small wooden dachas, rising above them with a neo-classical façade and fountain. The museum suffers from the presence of the current president too, but to a lesser extent than Alzhir. It is a bigger museum maintained on three floors so that the president's obligatory light blue room is not as impactful.

The displays are well curated and the reconstructed administration offices on the first floor give an immediate feeling for the environment in which administrators worked. Details of the geography and the ethnic composition of 
the prison population within KarLag are displayed and the rooms take the visitor beyond the Gulag to the struggle for Kazakh independence from the Soviet Union. Importantly though, neither Alzhir nor Dolinka concentrate solely on Kazakh suffering, and Spassk is dedicated to the foreign dead. Instead, these sites highlight the international character of victimhood in KarLag. This is on the one hand a simple matter of accuracy - KarLag's victims were very international. Perhaps fears of Russian separatism also make any appeal to Kazakh grievances off-limits.

As others have noted (Walby \& Piche 2011), memorialization aims at ideally creating a sense of authenticity for the visitor. Relics of the prison or camp are displayed with this goal in mind, though it may not have the intended effect. In Kazakhstan, like in Russia, there is a recognizable tendency to exhibit relics and personal artifacts in representing victimhood, and mannequins and mocked up cells, watchtowers and offices to represent the guards and the machinery of the Gulag's operation. In particular, this serves to create a degree of distance between the visitor or 'penal spectator' (Walby \& Piche 2011: 466) and the work and lives of the managers and maintainers of the Gulag. By extension, it serves to distance the visitor from a sense of the experiences of the victims in facing the enormous might of the Soviet penal state and the way in which this manifested itself in mundane and everyday penal interactions.

Thus, in Dolinka for example, visitors experience a manufactured wickedness. A rather comic-book evilness is generated by dark music - Orff's Carmina Burana for example - percolating through the museum display rooms. The artificial interrogation and torture cells reinforce this, complete with redpaint blood in the basement of the building. Alzhir also features 'interrogation displays' with mannequins and fake interrogation rooms. Yet at neither Alzhir or Dolinka was any actual interrogation carried out. The administration building at Dolinka had no cells or barracks, and those that arrived in Alzhir had already been interrogated, 'tried' and convicted thousands of miles away.

A clue as to why this sense of inauthenticity, and the distance it entails, exists so strongly at Kazakhstan's prison museums resides a couple of miles down the road on the way into Dolinka village. A working prison sits some way off the road, a sorry remnant of the once sprawling system of KarLag. The 
watchtowers, barbed wire and low buildings inside the walls clearly indicate that this is a colony, basically a small labour camp, still managed in many regards in the Soviet style. The mock-ups of watchtowers and prisoner dormitories in the museums are literally not that far from the actual conditions of prisons in Kazakhstan today.

\section{The Periphery: the Gulag in the Baltic States}

There are stark contrasts in how the Gulag is remembered and how this defines the nature of prison tourism outside the Gulag centre of Russia and Kazakhstan. In the Baltic States of Estonia, Latvia and Lithuania there has been a complete rejection of the Soviet past and an unashamed sense of discussing victimhood regardless of offending the Russian minorities within these states' territories. All the Baltic capital cities, Tallinn, Riga and Vilnius possess museums to Soviet occupation. All contain detail about the sufferings of their countrymen in the prisons and camps of the Gulag. There are good grounds to do so. Upon invasion by the Soviets in 1940, the Baltic States possessed a relatively educated,

urbanized and mobilized society with high degrees of national consciousness. The peoples of the Baltics were consequently repressed in the Gulag to a greater degree than most other nations, proportionate to their size.

In the present day, in contrast to Russia or Kazakhstan, these countries all have more robust democratic institutions, histories of democratic independent governments before the Soviet period, and a critical, often anti-Russian geopolitical stance having gained membership of the EU and NATO. Yet, importantly, all of these countries, with the exception of Estonia, maintain prison colonies that operate, despite intentions of reform, along Soviet lines. Thus, it is no less striking that prison tourism here is often mainly directed at remembering the exceptional practices of arrest, interrogation, torture, forced confession, transit or execution rather than the conditions of the colonies and camps themselves.

A key difference between the center and periphery in memorializing these practices however is the location of the museums. In countries such as Lithuania (in Vilnius) and Estonia (in Tartu) the old KGB buildings were re- 
appropriated as the ministries of Soviet control collapsed. While the Lubyanka building in Moscow remains the hub of the FSB, the successor to the KGB in Russia, in Vilnius the KGB building on the main Gedimino Avenue was converted into a museum. The KGB prison cells in the basement are now an exhibit, just as they are in Tartu's old KGB building.

While Kazakh victimhood is rather overlooked in the Gulag museums of Kazakhstan, in Lithuania the focus is very much on national trauma, from the Soviet invasion of 1940, to WWII, and the post-war deportations to the Gulag and the partisan struggle with the occupying Soviet forces in the Baltic forests into the 1950s and 60s. The KGB building basement in Vilnius reveals the original interrogation cells including a chilling execution chamber. No fake blood or spooky music here, no relics or mannequins, the site is maintained simply and speaks for itself.

Also in the basement, a heavy steel cell door from the Soviet period is on display from the Lukiskes remand prison only 15 minutes walk away. This prison, built in the late $19^{\text {th }}$ Century and still in operation, cannot be visited by tourists. Thus, the steel door, as a museum exhibit, is presumably intended to indicate the repression of people even after the KGB torture cells, once in remand, awaiting transfer to Siberia or Kazakhstan. Yet the door 'conceals continuities' (Walby \& Piche 2011; Brown 2009) - the uncomfortable fact is that the conditions of Lukiskes have hardly improved since the late Soviet period.

Latvia displays very similar characteristics in its approach to the Soviet past and the Gulag. Here however the easy consensus (among ethnic Latvians at least) about what the Gulag was and who its victims were has perhaps begun to push prison tourism towards unabashed entertainment, commodification and outright commercialization. While the museum of occupation in Riga is a suitably sober exhibition that details the consequences of the Nazi and Soviet occupations for Latvia, including mocked up prison camp barracks, the old site of Karosta prison, built in the $19^{\text {th }}$ century, in the west of the country provides a different perspective. Punters can buy tours of this prison 'theme park' and even overnight hotel packages. Actors simulate the behavior of prison guards, tourists play at being prisoners, crouching in cells and being shouted at (Daily Mail 2013). 
The KGB had used Karosta in the post-war period as a remand prison, the last place many people were held before journeying to the Gulag camps in Russia and Kazakhstan. Tourists now pay to experience KGB interrogation. Nearby in working prison colonies, actual prisoners endure Soviet-style dormitories of twenty or thirty people in which inmate violence is commonplace and often censured by the European Court of Human Rights (Baltic Times 2014).

Estonia, Latvia, and Lithuania maintain a number of other prison tourism sites connected in some way to the Gulag as well as the atrocities committed during WWII on the territories of these countries. Moreover, as the freest of the former Soviet states, students, researchers and other groups with the right permissions can visit working prison sites. For this reason, in one prison the author visited in Alytus, southern Lithuania, a 'museum cell' is maintained in the segregation unit to show the harshness of conditions in Soviet times to visitors. Under the Soviets, segregation meant solitary confinement and standing for the whole day. In independent Lithuania, those conditions have improved, but some aspects of Soviet segregation remain.

While in general most prison tourist sites the author has visited in the Baltics lack heavy commodification, dark tourism is certainly bigger here than in the Gulag 'centre' countries of Russia or Kazakhstan. Estonia has a tongue-incheek 'KGB museum' on the top floor of a once-bugged Soviet-era hotel, unthinkable in a country like Russia were ex-KGB men run the country. Moreover, the Baltic States, accessible to foreigners due to budget airlines, visafree regimes and membership of the EU, may have started to see an opportunity to market their experience behind the Iron Curtain to tourists possessing a macabre fascination with the penal excesses of the Soviet Union.

The Baltic States then contrast starkly with Russia or Kazakhstan. The Gulag is remembered grievously, the actual sites of repressive penal institutions are re-roled to house exhibits that attempt to access a direct sense of injustice and inhumanity, and the victims and perpetrators are not distanced from the visitor through mannequins and mock ups. Yet, the clarity and consensus over the past at the level of politics, despite the large Russian minorities living in the Baltics, has perhaps led to increasing commodification and promotion of dark tourism in these lands so blighted by historical catastrophes. Moreover, prison 
tourism still engages only limitedly with what this history means for the penal system in the present day.

The Baltic States are somewhat unique in the post-Soviet region. They were in the Soviet Union for less time than any other republics, are geographically much closer to Europe and have been helped by their proximity to Scandinavia. Their course since the collapse of the Soviet Union has been very distinct from all others. Prison tourism in this peripheral corner of the former Gulag reflects this. What of other Gulag periphery countries?

There is not space here to consider all of them, however, in general the uneasy relationship with the Gulag that characterizes Russia and Kazakhstan is more pervasive through the periphery than the certain stance of the Baltic States. A general impression is that many periphery countries simply do not engage in developing prison tourism due to a lack of debate about the Gulag past. This is particularly true of weak states such as Kyrgyzstan and Tajikistan and of closed and paranoid ones such as Turkmenistan.

Those countries that have close relations with Russia for cultural (Belarus) or security (Armenia) reasons also have no political incentive to highlight the Gulag as an object of tourism. Georgia, following war with Russia in 2008 and almost 10 years of a virulently pro-western government, opened its own museum to Soviet occupation in the capital Tbilisi in a similar vein to those of the Baltic States, though not on an old prison site.

Lastly, it is important to note that the Gulag and the Soviet prison experience competes in many countries with other historical traumas in the process of nation-building. ${ }^{1}$ Thus, for example, Armenia tends to focus resources on visitor sites connected with the 1915 Armenian genocide, while in Ukraine the great famine, the Holodomor, of 1932-33, or the 1985 disaster at Chernobyl is emphasized for the dark tourist. Yet given the situation in Ukraine, perhaps there is some scope for developing Gulag tourism. Relations with Russia are strained over Crimea and separatism in the east of the country. The Soviet past and its symbols have been demonized and are being removed from the streets of Ukrainian towns and cities. There is now every incentive to turn the sites and

\footnotetext{
${ }^{1}$ I am grateful to Matthew Light for this observation.
} 
practices of the Gulag into objects of tourist interest. Perhaps when this happens, the Baltic States will be used as a model.

\section{Concluding comments}

Every Soviet republic from Estonia to Tajikistan maintained penal institutions of the Gulag. Yet, in the present day, the form and content of prison tourism in the former Soviet Union varies greatly across the region. This chapter has been concerned with describing and to some extent explaining this variation. To do this, the chapter considered two regions where these contrasts stand out the most. In comparing Russia and Kazakhstan, the two principle sites of the Gulag camps, with the Baltic States, where fewer Gulag sites remain but the sense of victimhood is higher, the chapter found that prison tourism sites varied in significant ways. I have compared the physical locations of sites; the representations of victims and perpetrators; commercialization; and the degree to which museums juxtapose the past with the present.

Firstly, variation occurred in the physical locations of the sites. In the Soviet Union, carefully managed 'Gulag tourism' enabled foreigners to visit working prisons (Hardy 2012). Such access may well have been easier then than it is now. Few tourist sites in the region are on functioning penal locations. There is variation to the extent that they are even on former prison sites. Thus, for example, in the Baltics, museums are often housed in the former premises and dungeons of the state security services. This brings a direct sense of the physical space where suffering actually occurred. These museums, due to the buildings they are in and the gruesome presence of actual torture cells, concentrate the visitor's focus on the 'investigative' process, torture, forced confession and often execution of prisoners. The camps and colonies are places faraway, dealt with in displays. In Kazakhstan and Russia, museums do not exist in state security offices, but are often housed in bespoke, purpose built, buildings. Sometimes these are on the sites of camps that have physically disappeared, are faraway from population centres, or whose appearance is tightly controlled by the state.

Secondly, in Lithuania, Latvia and Estonia there is a greater consensus over what the Gulag was to these countries, and who the victims and 
perpetrators were. Thus, there is greater confidence in how to present and curate these museums, often letting sites speak for themselves. In Russia and Kazakhstan, there is a tendency to utilize mock-ups, mannequins and music in such a way as to produce a sense of artificiality, to distance the visitor from actual experience, and to stylize everyday oppression of prisoners in their interactions with guards and the prison regime. Moreover, political actors, such as Kazakhstan's verbose president, speak for the site rather than the site speaking for itself.

Thirdly, while across all the cases prison museum sites make an attempt to educate in a relatively somber way, in the Baltic States such museums sit unashamedly in town centres, making them accessible and major tourist sites. This confidence has, in some cases, led to commodification of sites, turning them into theme park-like spectacles rather unbefitting of the history they portray.

Fourthly, and perhaps most importantly, all the cases considered here share one thing in common - prison tourism in these countries exists in the shadow of the ongoing use of labour colonies, often operating along Soviet lines. Moreover, the former Soviet states, including the Baltic States, have the highest incarceration rates in Europe and some of the highest in the world. While so many prisoners continue to be victims of torture and forced confession, held in poor, communal conditions, governments across the region have no incentive to honestly draw tourist attention to prison conditions and the penal excesses of previous regimes. Prison tourism then, as elsewhere, conceals continuities. It attempts to establish difference and an 'othering' of the past.

Throughout the chapter, I have suggested certain explanations for why we see these differences and similarities across a region that shares the Gulag as a common historical trauma. It is impossible to fully explicate and analyse the factors here, but clearly the development of Gulag tourism reflects wider processes of nation-building, geopolitical orientations, the configuration of statesociety relations and the evolving divergence of post-Soviet political systems. These factors surely impact the way that the Gulag is remembered and thus the nature of prison tourism in these countries. How exactly these factors impact decision-making regarding the funding, development and curating of prison museums would be the topic of a separate research agenda. 


\section{Bibliography}

Amos H. 2015. New Museum Stakes Claim to Russia's Gulag Legacy. Moscow Times. 05.11.2015. Available at: http://www.themoscowtimes.com/arts n ideas/article/new-museumstakes-claim-to-russias-gulag-legacy/542211.html [Accessed 05.10.2015]

Applebaum, A. (2003). Gulag: A history. Random House LLC.

Bacon, E. (1994). The Gulag at war: Stalin's forced labour system in the light of the archives. Macmillan Press.

Barnes, S. A. (2011). Death and Redemption: the Gulag and the Shaping of Soviet society. Princeton University Press.

Borodkin, Leonid, Paul R. Gregory, and Oleg Khlevniuk, eds. GULAG: Ekonomika prinuditel'nogo truda. Moscow: Rosspen, 2005.

Brown, M. (2012). Empathy and punishment. Punishment \& Society, 14(4), 383-401.

Brown, M. (2009). The culture of punishment: Prison, society, and spectacle. New York: NYU Press.

Daily Mail. 2013. Not exactly a relaxing vacation: Inside the hotel converted from a prison where guests are punished with physical exercise for the full 'inmate experience'. Available at: http://www.dailymail.co.uk/news/article-2358086/Karosta-Prison-Inside-converted-hotelguests-verbally-abused-sleep-concrete-floors.html\#ixzz3hTanXUBL [Accessed 31.07.2015]

Etkind, A. (2013). Internal colonization: Russia's imperial experience. John Wiley \& Sons.

Graudt S. 2003. Lock Down at Vladimir Central Prison. The Moscow Times. 22.08.2003. Available at: http://www.themoscowtimes.com/arts n $\mathrm{n}$ ideas/article/lock-down-at-vladimir-centralprison/358699.html [Accessed 31.07.2015]

Gregory, P. R., \& Lazarev, V. (Eds.). (2003). The economics of forced labor: The Soviet Gulag (Vol. 518). Hoover Institution Press.

Hardy, J. (2012) Gulag Tourism: Khrushchev's “Show” Prisons in the Cold War Context, 1954-1959. Russian Review 71. 49-78

Isachenkov V. 2010. Putin: Solzhenitsyn's Gulag Archipelago 'essential'. The Washington Times. 26.10.2010. Available at: http://www.washingtontimes.com/news/2010/oct/26/putinsolzhenitsyns-gulag-archipelago-essential/ [Accessed 31.07.2015]

King, R. D. (1994). RUSSIAN PRISONS AFTER PERESTROIKA End of the Gulag?. British Journal of Criminology, 34(S1), 62-82.

Kharkhordin, O. (1999). The collective and the individual in Russia: A study of practices (Vol. 32). Univ of California Press.

MacFarquhar N. 2015. Tug of war over Gulag history in Russia's North. New York Times. 30.08.2015. Available at: http://www.nytimes.com/2015/08/31/world/europe/russians-clash-overcommemorating-monasterys-grim-past.html?s smid=fb-share\& $\mathrm{r}=1$ [Accessed 12.11.2015] 
Piacentini, L., \& Slade, G. (2015). Architecture and attachment: Carceral collectivism and the problem of prison reform in Russia and Georgia. Theoretical Criminology, 19(2), 179-197.

Oliphant, R. 2015. Russia's only Gulag museum faces closure. The Daily Telegraph. 18.03.2015. Available at: http://www.telegraph.co.uk/news/worldnews/europe/russia/11481113/Russiasonly-gulag-museum-faces-closure.html [Accessed 31.07.2015]

Radio Free Europe. 2014. Justice Ministry asks to close Memorial Rights Group. Available at: http://www.rferl.org/content/russia-closing-of-memorial-rights-group-/26631357.html [Accessed 31.07.2015]

Ross, J. I. (2012). Touring imprisonment: A descriptive statistical analysis of prison museums. Tourism Management Perspectives, 4, 113-118.

Shevtsova, L. (2010). Putin's Russia. Carnegie Endowment.

Springe I. 2014. Crimes During Punishment Re:Baltica Investigates Life in Baltic Prisons 03.12.2014 Available at: http://www.baltictimes.com/crimes_during_punishment_re_baltica_investigates_life_in_balt ic prisons/ Accessed [31.07.2015]

Viola, L. (2007). The unknown gulag: the lost world of Stalin's special settlements. Oxford University Press.

Walby, K., \& Piche, J. (2011). The polysemy of punishment memorialization: Dark tourism and Ontario's penal history museums. Punishment \& Society, 13(4), 451-472.

Welch, M., \& Macuare, M. (2011). Penal tourism in Argentina: Bridging Foucauldian and neoDurkheimian perspectives. Theoretical Criminology, 15(4), 401-425. 